\title{
Short Communication: A new primer set in CHD1 gene for bird sex identification
}

\author{
FEBRIYANTI VERA ${ }^{1}$, WORAWIDH WAJJWALKU ${ }^{2}$, PRAMANA YUDA $^{3, \bullet}$, BUDI SETIADI DARYONO $^{4, \bullet \bullet}$ \\ ${ }^{1}$ Graduate Program, Department of Tropical Biology, Faculty of Biology Universitas Gadjah Mada. Jl. Teknika Selatan, Sekip Utara, Sleman 55281, \\ Yogyakarta, Indonesia \\ ${ }^{2}$ Akkharatchakumari Veterinary College, Walailak University. 222 Thaiburi, Thasala District Nakhonsithammarat 80160, Thailand \\ ${ }^{3}$ Department of Biology, Faculty of Biotechnology, Universitas Atma Jaya Yogyakarta. Jl. Babarsari No. 44, Depok, Sleman 55281, Yogyakarta, \\ Indonesia. Tel.: +62-274-487711, Fax.: +62-274-487748, "email: pramana.yuda@uajy.ac.id \\ ${ }^{4}$ Laboratory of Genetics and Breeding, Department of Tropical Biology, Faculty of Biology, Universitas Gadjah Mada. Jl. Teknika Selatan, Sekip Utara, \\ Sleman 55281, Yogyakarta, Indonesia. Tel.: +62-274-580839, Fax.: +62-274-649235, "email: bs_daryono@mail.ugm.ac.id
}

Manuscript received: 23 July 2021. Revision accepted: 24 October 2021.

\begin{abstract}
Vera F, Wajjwalku W, Yuda P, Daryono BS. 2021. Short Communication: A new primer set in CHD1 gene for bird sex identification. Biodiversitas 22: 4977-4982. Determine sex is difficult for many bird species that are sexually monomorphic or only dimorphic in the adult stage. Many molecular markers have been developed for DNA sexing, which were mostly based on identifying Z and $\mathrm{W}$ chromosomes of avians. The sex determination of birds was mostly applied universal primer set such as P2/P8 or 2550F/2718R. However, those universal primers that were designed sometimes could not good result consistency in non-ratite birds or ratite birds. Therefore, we improved a specific primer design with deletion site in $\mathrm{W}$ chromosome to amplify the female-specific segments on Chromodomain-helicase DNA binding protein-1 (CHDI) gene from alignment sequences CHDI-Z and CHDI-W of Macrocephalon maleo S. Müller, 1846. This study aims to design a new pair of primer targeting a section of the CHDl gene that can be amplified in non-ratite birds, the name of a new primer is In-Sex F/In-Sex R. A new primer set amplified DNA fragments in around 650 or 550 base pairs of $C H D 1-Z$ and also, 350 base pairs of $C H D 1-W$. The result has successfully amplified the sex of multiple species on orders Galliformes, Passeriformes, Accipitriformes, and Strigiformes. This analysis can be helpful to the effort of in-situ or ex-situ management and conservation programs e.g the mating system in birds. And also, the analysis can be helpful for sexing data in the case of captive birds before releasing in natural habitat or reintroduction programs.
\end{abstract}

Keywords: Avian, CHDl gene, molecular sexing, primer set, $\mathrm{Z}$ and $\mathrm{W}$ chromosomes

\section{INTRODUCTION}

Indonesia is listed as a mega biodiversity country. This country is only $1.3 \%$ of the world's total land but it possesses enormous biological richness. The listed birds in Indonesia cover $17 \%$ of the world (Sukardiyono and Rosana 2019). The summary of biodiversity lives in the Wallacea region. The diversity of birds in this area is 711 with 274 endemic bird species (it covers $40 \%$ of bird biodiversity in Indonesia). One example of endemic species in the Wallacea region is Macrocephalon maleo S. Müller 1846 (Yuni and Yuda 2019).

The effort to protect those birds is conducted through in-situ or ex-situ conservation. Several efforts in ex-situ conservation have been successfully conducted in Indonesia such as ex-situ conservation in the ZOO, ex-situ conservation in captive breeding, collection and documentation of fauna specimen and DNA genome as genetic resources in Division of Zoology, Research Center for Biology, Indonesian Institute of Sciences (LIPI) (Sulandari and Zein 2012). While, in-situ conservation programs such as Single Strand Conformation Polymorphism (SSCP), Restriction Fragment Length Polymorphism (RFLP), Random Amplified Polymorphic DNA (RAPD), Amplified Fragment Length Polymorphism (AFLP), Microsatellites, Allele-specific PCR
(AS-PCR), Capillary electrophoresis, Real-time quantitative PCR (qPCR) using TaqMan probes, and Real-time PCR combined with melting curve analysis (Morinha et al. 2012).

Sex determination is an important parameter of ineffective mating, behavioral, genetic, evolutionary, and ecological studies (Bermudes-Hamuran et al. 2002). In addition, accurate sex typing is a serious pitfall in many scientific, breeding and conservation programs. Over $50 \%$ of the world's bird species, nestlings, and adult individuals show no sexual dimorphism (Kroczak et al. 2021). And also, sex determination is the important thing on a population or sex ratio of the population before reintroduction program (Insee et al. 2014).

The traditional methodologies used for the sex determination analysis of birds by (1) behavioral observation, (1) presence of brooding patch, (3) differences in morphometric traits, (4) examination of the gonads by laparotomy or laparoscopy, (5) cloacal examination, (6) fecal steroid sexing and (7) cytogenetic analysis. Some disadvantages of those methods are time-consuming and in some cases, invasive and harmful (Morinha et al. 2012; Khaerunnisa et al. 2013). To avoid these limitations, in the mid-1990s, molecular techniques for avian sexing were improved such as the PCR-based technique (Morinha et al. 2012). 
The report on PCR-based gender determination approaches and sex-linked markers in avian species are steadily increasing. A continuous effort was made in PCRbased sex determination techniques to increase accuracy, speed and high-throughput applicability through previous reports (Dhanasekaran et al. 2016). DNA-based methods for molecular sexing need sex-linked-markers, mostly using Chromodomain-helicase DNA binding protein-1 ( $C H D 1)$ gene which is one of the conserved areas in sexlinked Z and W chromosomes (Griffiths et al. 1998). CHD1 gene-based PCR amplification proved to be a reliable, generally accurate and satisfactory technique for sex identification of avian species of diverse phylogenetic backgrounds (Cakmak et al. 2017).

Chromodomain-helicase DNA binding protein-1 $(C H D 1)$ gene is an ATP-dependent chromatin remodeling protein that is conserved throughout eukaryotes. This gene can assemble and organize nucleosomes, we can analyze with in-vitro or in-vivo approaches, usually conserved area coding in area domain gene to use amplify sex-linked in many birds (Mohanty et al. 2016). CHDl gene in avian has 3 areas domain are Chromo (chromatin organization modifier) domain, Helicase (SNF2-linked) domain or called ATPase domain and DNA-binding domain. CHDI gene-linked chromosome sex of avian, as markers, will amplify fragment DNA CHD1-ZZ or CHD1-ZW of avian. The male bird has homogametic sex (two copies of the $Z$ chromosome) and the female bird has heterogametic sex (sex Z and $\mathrm{W}$ chromosomes) (Fridolfsson and Ellegren 2000).

Some laboratories have used specific primers to get the female-specific bands through PCR and the segments of PCR products have been proved to be different from each other (Ramos et al. 2009; Liu et al. 2011) i.e sex determination of chicken by PCR using W chromosomespecific primers was already done in two $\mathrm{W}$ chromosome linked EST genes targets form cDNA microarray 2d-1H5 (Acc. No: AB188532) and 2d-2D9 (Acc.No: AB188526) by Dhanasekaran et al. (2016). One of the most commonly used bird determination sex is P2/P8 in the CHDl gene, which has been able to sex approximately $80 \%$ of nonratite species. However, some species from different taxa (i.e. eagles, pelicans, geese, petrels, albatross, dove, and pigeon) could not be determined their sexes with this primer set (He et al. 2013; Dawson et al. 2016). In addition, difficulty in the genetically determined sex of most ratites birds can only be determined sex using species-specific markers (Dawson et al. 2016).

The most common primer set used for sex determination of birds is $\mathrm{P} 2 / \mathrm{P} 8$ and also, 2550F/2718R primer set was developed as a 'universal primer' for sexing different bird species (He et al. 2013). Those primer sets were designed to amplify linked-sex with different locus in the $C H D 1$ gene. The primer set P2/P8 was developed by Griffith et al. (1998) at a locus in the partial $22^{\text {nd }}$ and $23^{\text {rd }}$ exons in the CHDl gene. Meanwhile, the primer set $2550 \mathrm{~F} / 2718 \mathrm{R}$ was conducted by Fridolfsson and Ellegren (1999) at a locus in the partial $15^{\text {th }}$ and $16^{\text {th }}$ exons in CHD1 gene (Insee et al. 2014).
The results of sex determination in birds with those primer sets were sometimes inconsistent successful to amplify the CHDl gene-linked chromosome sex of some taxa the avians. The research Sulandari and Zein (2012) reported that the P2/P8 primer set did not successfully amplified the $C H D 1$ gene-linked chromosome sex of the bird of Psittacidae and Bucerotidae. In addition, P2/P8 primer set needs post-PCR digestion with a restriction enzyme such as BamHI or HaeIII to obtain distinguishing fragments $C H D 1-Z$ and $C H D 1-W$ (Romanoev et al. 2019). Using a primer set 2550F/2817R, Yuda and Saputra (2020) identified the sexes of Maleo Senkawor (Macrocephalon maleo) chicks. However, the primer set was only successfully identified the sexes of $63.7 \%$ of 162 chicks. This study aims to design a new primer set that can improve their stability to successfully identify the sex of Macrocephalon maleo birds and its effectiveness in successfully identifying the sex of other bird species.

\section{MATERIALS AND METHODS}

\section{Samples}

In total, we examined twenty-seven domestic and wild bird species across 4 orders and 5 families (Table 1), including Accipitriformes (1 family, 2 species), Passeriformes (3 families, 3 species), Strigiformes (1 family, 1 species), and Galliformes ( 2 families, 3 species). The DNA samples of these birds are the DNA collection of Laboratory of Biomolecular, Faculty of Biotechnology, Universitas Atma Jaya Yogyakarta, Indonesia. The DNA was isolated from various types of tissue samples from post-hatched egg-shell membrane, feather, and blood; using various types of extraction methods or kits (i.e. PCE, Favorgen kit, CTAB, silica, Qiagen kit and, gSYNC ${ }^{\mathrm{TM}}$ DNA Extraction Kit (Geneaid)). All samples were checked to the absorbance purify DNA. The absorbance (A) was measured by ultraviolet spectrophotometer with a ratio of $\mathrm{A}_{260} / \mathrm{A}_{280}$. It was used to express the DNA purity and the mass concentration appropriate to the A value.

\section{Primer design}

New primer set was designed manually based on the published $C H D 1-Z$ and $C H D 1-W$ sequences (Acc. No: MT074328.1 and Acc.No: MT074330.1) of Macrocephalon maleo (Yuda and Saputra 2020). Those sequences were a result of the amplification of $C H D 1$ using primer set 2550F/2718R developed by Fridolfsson and Ellegren (1999). Multiple alignments of those sequences were done with CLUSTAL-W method of GeneStudio software and BioEdit version 7.2.6 software. Specific deletion of the female fragment $(C H D 1-W)$ in between exon locus 16 CHDl gene as modified for sexing form $2550 \mathrm{~F}$ and $2718 \mathrm{R}$. We designed primer forward named InSex-(F) (5' - TTT CTC TCA GAT GGT GAG GAT G 3') 22 mer base and primer reverse named InSex-(R) (5'TGA TCC ATC AAG TCT CTA AAG AG -3') 23 mer base. The site position of this primer forward at 79 until 100 on site basepair while, primer reverse at 549 until 570 on site basepair (Figure 1). 
Table 1. List of samples in this study

\begin{tabular}{|c|c|c|c|c|c|c|}
\hline Order & Family & $\begin{array}{c}\text { Status IUCN } \\
\text { Red list }\end{array}$ & $\begin{array}{c}\text { Species, binomial } \\
\text { name }\end{array}$ & $\begin{array}{c}\text { Sample } \\
\text { code }\end{array}$ & Tissue & $\begin{array}{c}\text { DNA isolation } \\
\text { method }\end{array}$ \\
\hline \multirow[t]{2}{*}{ Accipitriformes } & Accipitridae & $\begin{array}{l}\text { Least } \\
\text { Concern (LC) } \\
(2020)\end{array}$ & $\begin{array}{l}\text { Nisaetus cirrhatus } \\
\text { (Gmelin, 1788) }\end{array}$ & $\begin{array}{c}\text { KBGL } \\
01\end{array}$ & Blood & Qiagen Kit \\
\hline & & $\begin{array}{l}\text { Least } \\
\text { Concern (LC) } \\
(2016)\end{array}$ & $\begin{array}{l}\text { Haliastur indus } \\
\text { (Blyth, 1865) }\end{array}$ & $\begin{array}{c}\text { KBGL } \\
02\end{array}$ & Blood & Qiagen Kit \\
\hline \multirow[t]{7}{*}{ Passeriformes } & Passeridae & $\begin{array}{l}\text { Least } \\
\text { Concern (LC) } \\
(2017)\end{array}$ & Passer montanus & GRJ 1 & Blood & PCE \\
\hline & Estrildidae & Least & Lonchura fuscans & BK1 & Blood & PCE \\
\hline & & Concern (LC) & (Cassin, 1852). & BK2 & Blood & PCE \\
\hline & & (2016) & & BK3 & Blood & PCE \\
\hline & & & & BK5 & Blood & PCE \\
\hline & Pycnonotidae & Critically & Pycnonotus & $\mathrm{CR} C$ & Blood & PCE \\
\hline & & $\begin{array}{l}\text { Endangered } \\
\text { (CR) (2018) }\end{array}$ & $\begin{array}{l}\text { zeylanicus (Gmelin, } \\
1789 \text { ) }\end{array}$ & CR D & Blood & PCE \\
\hline Strigiformes & Tytonidae & $\begin{array}{l}\text { Least } \\
\text { Concern (LC) } \\
(2019)\end{array}$ & $\begin{array}{l}\text { Tyto alba } \\
\text { (Scopoli, 1769) }\end{array}$ & TA185 & Feather & Silica \\
\hline \multirow[t]{3}{*}{ Galliformes } & Phasianidae & $\begin{array}{l}\text { Least } \\
\text { Concern (LC) } \\
(2016)\end{array}$ & Gallus gallus & $\begin{array}{l}\mathrm{AJ} \\
\mathrm{AB}\end{array}$ & $\begin{array}{l}\text { Blood } \\
\text { Blood }\end{array}$ & $\begin{array}{l}\text { Favorgen kit } \\
\text { Favorgen kit }\end{array}$ \\
\hline & & $\begin{array}{l}\text { Endangered } \\
(\mathrm{EN})(2018)\end{array}$ & $\begin{array}{l}\text { Pavo musticus } \\
\text { (Linnaeus, 1766) }\end{array}$ & $\begin{array}{l}\text { MH01 } \\
\text { MH03 }\end{array}$ & $\begin{array}{l}\text { Blood } \\
\text { Blood }\end{array}$ & $\begin{array}{l}\text { Silica } \\
\text { Silica }\end{array}$ \\
\hline & Megapodiidae & $\begin{array}{l}\text { Endangered } \\
(\mathrm{EN})(2016)\end{array}$ & $\begin{array}{l}\text { Macrocephalon } \\
\text { maleo } \\
\text { (S. Müller, 1846) }\end{array}$ & $\begin{array}{l}\text { MT10 } \\
\text { MT15 } \\
\text { MT20 } \\
\text { MT27 } \\
\text { MT31 } \\
\text { MM04 } \\
\text { MM06 } \\
\text { MB05 } \\
\text { MB12 } \\
\text { MH44 } \\
\text { MH48 } \\
\text { MO33 } \\
\text { MO34 } \\
\end{array}$ & $\begin{array}{l}\text { Eggshell membrane } \\
\text { Eggshell membrane } \\
\text { Eggshell membrane } \\
\text { Eggshell membrane } \\
\text { Eggshell membrane } \\
\text { Eggshell membrane } \\
\text { Eggshell membrane } \\
\text { Eggshell membrane } \\
\text { Eggshell membrane } \\
\text { Eggshell membrane } \\
\text { Eggshell membrane } \\
\text { Eggshell membrane } \\
\text { Eggshell membrane }\end{array}$ & $\begin{array}{l}\text { Geneaid kit } \\
\text { Geneaid kit } \\
\text { Geneaid kit } \\
\text { Geneaid kit } \\
\text { Geneaid kit } \\
\text { Geneaid kit } \\
\text { Geneaid kit } \\
\text { Geneaid kit } \\
\text { Geneaid kit } \\
\text { Geneaid kit } \\
\text { Geneaid kit } \\
\text { Geneaid kit } \\
\text { Geneaid kit } \\
\end{array}$ \\
\hline
\end{tabular}

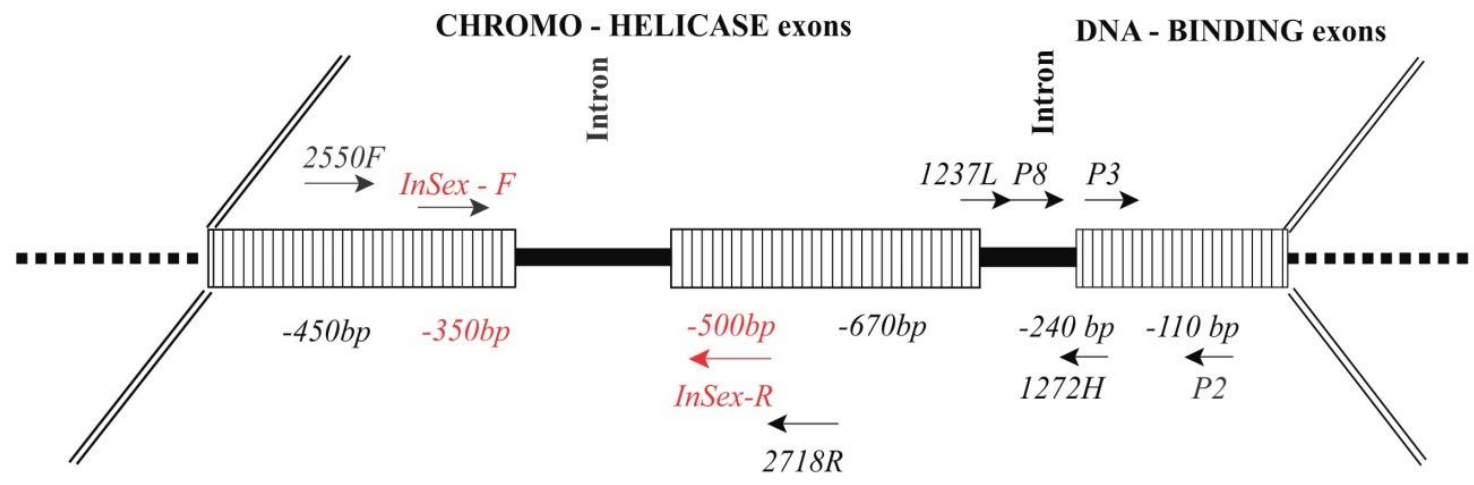

Figure 1. Location of the CHD1 gene-based sexing PCR primers (not on an exact scale): 2550F/2718R, 1237L/1272H, P8/P2, P2/P3 and new primer set (InSex-F/InSex-R) adapted from reference Romanov et al. 2019 
Exact positions of the primers on the chicken $\mathrm{Z}$ chromosome are: $2550 \mathrm{~F}(51,125,443-51,126,015) ; 2718 \mathrm{R}$ $(51,126,015$ - 51,126,035); P8 (51,129,765-51,129,784); $1237 \mathrm{~L} \quad(51,129,776-51,129,794) ; \quad 1272 \mathrm{H} \quad(51,129,992-$ $51,130,011) ; \quad$ P3 $(51,130,000-51,130,022) ;$ and P2 $(51,130,090-51,130,109)$ (Romanov et al. 2019). So, a new design primer set approximately $2550 \mathrm{~F} \quad(51,125,443$ $51,126,015) ; 2718 \mathrm{R}(51,126,015-51,126,035)$ on scale the chicken $\mathrm{Z}$ chromosome (Figure 1).

\section{Molecular technique with PCR procedure}

Molecular technique to test the primer set the genomic DNA was used PCR procedure. The positive control was used with female and male chicken sample. The template in PCR reactions in volume $10 \mu \mathrm{L}$ containing $1 \mu \mathrm{L}$ of genomic DNA with standard concentrated $20 \mathrm{ng} / \mathrm{uL}, 0.2$ mm dNTPs, 2X reaction PCR buffer, 1 U KOD Polymerase FX Neo (Toyobo, Osaka, Japan), $10 \mu \mathrm{M}$ new design primer InSex-(F) [5'- TTT CTC TCA GAT GGT GAG GAT G 3'] and $10 \mu \mathrm{M}$ primer InSex-(R) [5'- TGA TCC ATC AAG TCT CTA AAG AG -3']. PCR condition was used predenaturation $94^{\circ} \mathrm{C}$ for 2 minutes, denaturation $98^{\circ} \mathrm{C}$ for 15 seconds, annealing $55^{\circ} \mathrm{C}$ for 30 seconds, extension $68^{\circ} \mathrm{C}$ for 45 seconds, final extension $68^{\circ} \mathrm{C}$ for 7 minutes, the step of denaturation until extension were used 39 cycles. PCR products were separated by running on $2 \%$ agarose gel and stained with flourosafe.

\section{RESULTS AND DISCUSSION}

\section{Primer design}

The improved designed sets of PCR primers $2550-\mathrm{F}$ and 2718-R able more good results to identify sex-linked for Macrocephalon maleo, a new design primer set has sensitivity amplifies CHD1Z and CHD1W cDNA sequences that amplify genomic DNA and deduce the location of introns within the coding sequence. i.e located in a region conserved between the two genes (Ellegren and Fridolfsson 1999).

The design of a new primer set on exon position (coding region) between flanked intron (non-coding region) of orthologous DNA regions. The new primer has a forward position at exon 15 and reverse position at partial exon 16 based on Insee et al. (2014) research. The specific CHD1-W gene site position has one deletion base to amplify the $\mathrm{W}$ chromosome that would likely impact mismatch to create two "alleles" if heterozygous, which could be distinguished by Sanger sequencing (Simsek and Adnan 2000; Stevens et al. 2017). We chose that site with considering requires good primer characteristics (Wang 2016; Bustin et al. 2020) also, indel polymorphisms are less frequent in exonic regions than in intronic regions so the primer designed to hybridize DNA to exonic regions would be more likely to amplify readable sequences (Tezuka et al. 2012).

Successful and reliable PCR requires efficient and specific amplification of the product, using chemically synthesized oligonucleotides as DNA primers. The target sequence and designing primers substantially affect the efficiency of your PCR. The designed primer must be followed by some that require good primer characteristics (Wang 2016). In general terms, the good primer's characteristic following parameters as making the ideal length for primer between 18 until 24 nucleotides, a melting temperature $(\mathrm{Tm})$ should be between $50^{\circ} \mathrm{C}$ until $65^{\circ} \mathrm{C}$, GC content ideally of around $50 \%$, absence of dimerization and hairpin capability and primer sequence shall be unique in the template DNA (Wang 2016; Bustin et al. 2020).

\section{Primer test}

The results of the molecular sexing test with this primer set: InSex-F/InSex-R can amplify different order avian to determine the sex of male or female. Twenty-five species were successfully sexed, including Galliformes, Passeriformes, Accipitriformes and Strigiformes (Figure 3 and 4).

In these trials of multiple species (Figure 3 and 4), there was a variation in PCR product length depending on the species or family. Variation PCR product length indicated different intronic sizes in $C H D 1$ gene between order or family avian. In DNA-based sexing using Polymerase Chain Reaction (PCR) in conserved CHDl gene is amplified with specific primers that give distinct banding patterns an agarose gel as a result of intronic regions within this gene (Ellegren 1996; Cakmak et al. 2017; Romanov et al. 2019).

We expected that female birds would show two bands with the lower band or lower fragment as heterozygous Wchromosome in sex chromosomes. The result of determination sex on this study, fifteen samples were female and ten samples were male. The upper bands or fragments (CHDI-Z) had amplified around $600 \mathrm{bp}-500 \mathrm{bp}$ depending on the family species, while the lower bands or fragments $(C H D 1-W)$ had amplified on $350 \mathrm{bp}$. The lower fragments or CHD1-linkage $\mathrm{W}$ chromosome does not have different amplified in multiple species cause low levels variability of $C H D$ l-linkage $\mathrm{W}$ chromosome is really conserved area in natural selection included selective sweeps and small effective population sizes (Lee et al. 2002).

Amplification showed this primer can determine the gender in sexually monomorphic birds of Macrocephalon maleo birds with well (Figure 3) however, two samples MH44 and MH48 have not the result amplify with well. It can cause the pure samples to be eggshell membrane containing DNA lower or risk DNA contamination than blood or feather (Cerit and Avanus 2007b). Regardless of the source the DNA extraction method affects the good quality purify and concentration of isolated DNA which, consider to stabilize nucleic acids against degradation, remove amplification inhibitors and concentrate the nucleic acid material into an appropriate volume of an aqueous solution compatible with the downstream application. Some DNA extraction methods were used in this study (Table 1) and the result amplification (figure 3 and 4) showed samples that used extraction kits have the best good result (Aghová 2020). Another case factor of sextyping data causes allelic dropout (ADO), it is a failed amplification of an allele which usually happens when the concentration of the DNA sample is low (Ivan and 
Parikesit 2019). ADO is possible for any autosomal or sex locus but is more likely for sex-typing markers (Dawson et al. 2016).

The primer set InSex-F/InSex-R is able to sensitive primer sexing for non-ratite birds also, this primer set can determine sex non-ratite birds with different order or family species. It is informative in species that are difficult to determine sex with universal primer set for especially helping identified sex of non-morphological look or monomorphic birds and only sexually dimorphic in adult stage in cases i.e analyses captive-bird and inbreeding programs in conservation habitat.

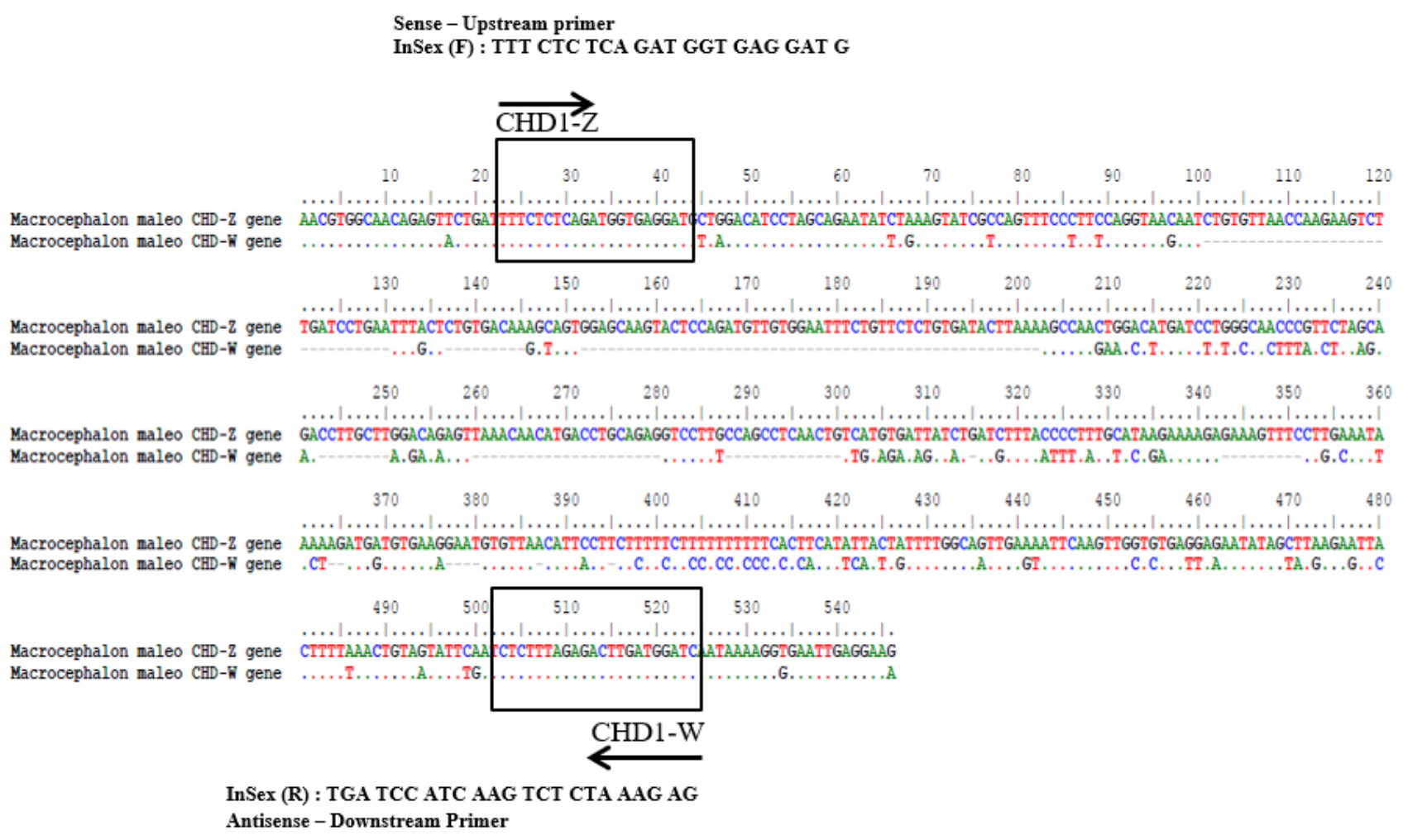

Figure 2. Alignments CHD-Z gene MB05 (male) and CHD-W gene MT10L (female) primer 2550F /2718R

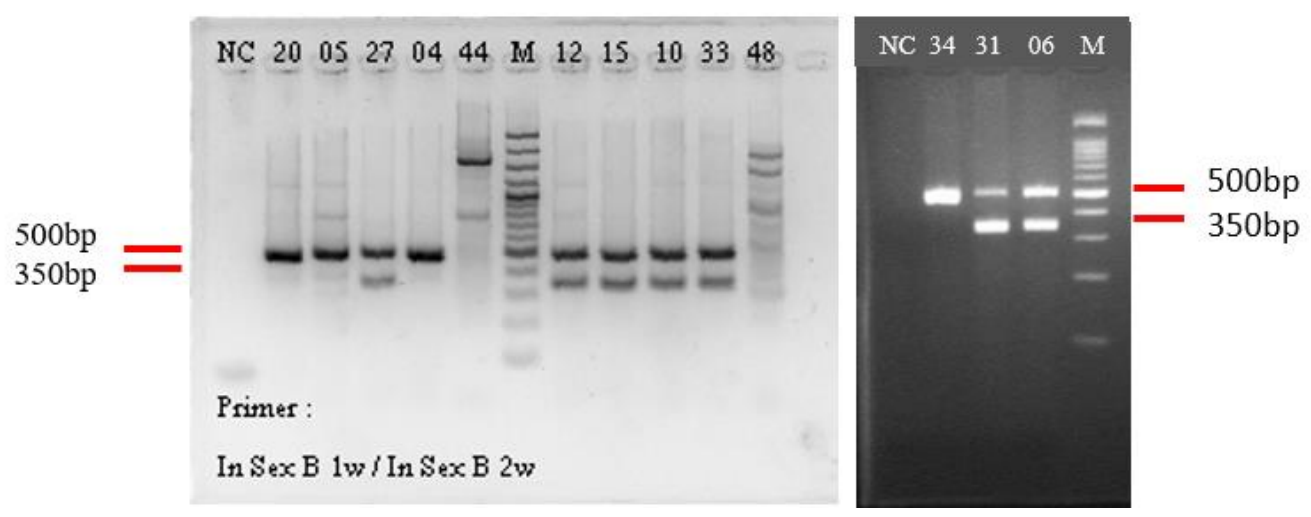

Figure 3. Molecular sexing of Macrocephalon maleo birds using PCR amplification of the CHD1 gene with primer InSex-F and InSex$\mathrm{R}$, markers 100 bp DNA Ladder, NC (negatives control). $\hat{\sigma}=\mathrm{MT20}, \mathrm{MB}$ 05, MO34, MM04 [one fragment/band $(\mathrm{ZZ})$ ]. $+=\mathrm{MT} 27$, MB12, MT15, MT10, MO33, MT31, MM06 [two fragment/band (ZW)] 


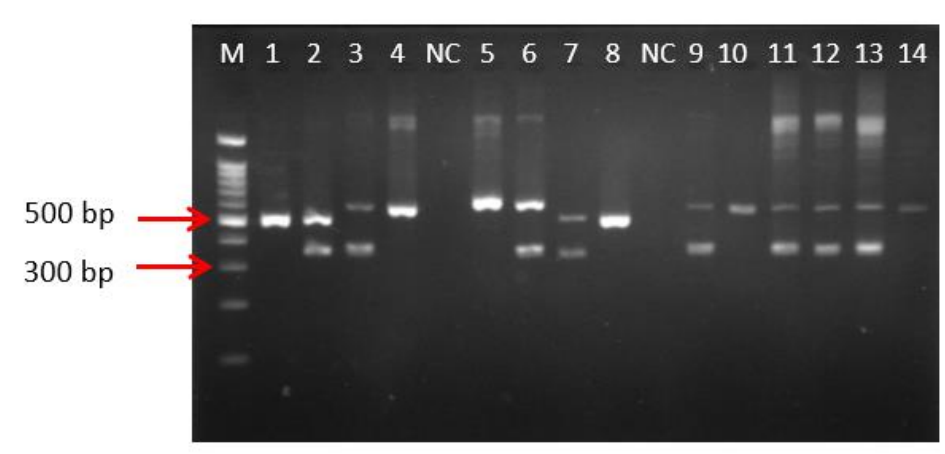

\begin{tabular}{|ll|}
\hline 1. AJ & 8. MH03 \\
2. AB & 9. GRJ01 \\
3. CR C & 10. TA185 \\
4. CR D & 11. BK01 \\
5. KBGL01 & 12. BK02 \\
6. KBGL 02 & 13. BK03 \\
7. MH01 & 14. BK05 \\
\hline
\end{tabular}

Figure 4. Molecular sexing of the domestic chickens (1,2); eagles (5,6); sparrows (3,4,9); owl (10); peafowls (7,8); and bulbuls (11-14) using PCR amplification of the CHD1 gene with primer InSex-F and InSex-R, marker $100 \mathrm{bp}$ DNA Ladder, NC (negatives control). ${ }^{\lambda}$ : AJ, CR D, KGBL1, MH03, TA185, BK5 [one fragment/band (ZZ)]. o.: AB, CR C, KBGL02, MH01, GRJ01, BK1, BK2, BK3 [two fragment/band (ZW)]

\section{ACKNOWLEDGEMENTS}

The authors would like to thank Molecular Biology Laboratory, Universitas Atma Jaya Yogyakarta, Indonesia for the Lab facility and permit to use their DNA vouchers for this study.

\section{REFERENCES}

Aghová IM. 2020. Comparison of 12 DNA extraction kits for vertebrate samples. Anim Biodiver Conserv 43 (1): 67-77. DOI: 10.32800/abc.2020.43.0067.

Bermudez-Humaran LG, Garcia-garcia A, Leal-Garza CH, Riojas-Valdes VM, Jaramillo-Rangel G, Montes R. 2002. Molecular sexing of monomorphic endangered ara birds. J Exp Zool 292 (1): 677-680 DOI: $10.1002 /$ jez.10070.

Bustin SA, Mueller R, Nolan T. 2020. Parameters for successful PCR primer design. Methods Mol Biol 2065: 5-22. DOI: 10.1007/978-14939-9833-3_2.

Cakmak E, Peksen CA, Bilgin CC. 2017. Comparison of three different primer sets for sexing birds. J Vet Diagn Invest 29 (1): 59-63. DOI: DOI: $10.1177 / 1040638716675197$.

Cerit H, Avanus K. 2007b. Sex determination by CHDW and CHDZ genes of avian sex chromosomes in Nymphicus hollandicus. Turk $\mathrm{J}$ Vet Anim Sci 31: 371-374.

Dawson AD, Remedios N, Horsburgh GJ. 2016. A new marker based on the avian Spindlin gene that is able to sex most birds, including species problematic to sex with CHD markers. Zoo Biol 35 (6): 533545. DOI: $10.1002 /$ zoo. 21326

Dhanasekaran S, Raj GD, Vignesh AR, Selvan ST, Prakash B, Perumal P, Arivudainambi S, Babu TG. 2016. Gender identification in chicken (Gallus gallus) by PCR using whole blood and dried blood spot on filter paper as template: without prior DNA isolation. BioRxlv 046888. DOI: $10.1101 / 046888$.

Ellegren H. 1996. First gene on the avian W chromosome (CHD) provides a tag for universal sexing of non-ratite birds. Proc R Soc Lond B Biol Sci 263 (1377): 1635-1641. DOI: 10.1098/rspb.1996.0239.

Fridolfsson AK, Ellegren H. 1999. A simple and universal method for molecular sexing of non-ratite birds. J Avian Biol 30 (1): 116-121. DOI: $10.2307 / 3677252$.

Fridolfsson AK, Ellegren H. 2000. Molecular evolution of the avian $\mathrm{CHD} 1$ genes on the $\mathrm{Z}$ and $\mathrm{W}$ sex chromosomes. Genet Soc Am 155 (1): 1903-1912.

Griffiths R, Double MC, Orr K, Dawson RJG. 1998. Short communication: A DNA test to sex most birds. Mol Ecol 7: 10711075 .

He X, Qing BP, Han JL, Ding CQ. 2013. Improved molecular assay for sex identification of the endangerd crested ibis (Nipponia Nippon) based on the CHD1 gene and a sex-linked microsatellite locus. Zool Sci 30 (9): 742-747. DOI: 10.2108/zsj.30.742.

Insee J, Kamolnorranath S, Baicharoen S, Chumpadang S, Sawasu W, Wajjwalku W. 2014. PCR-based method for sex identification of eastern sarus crane (Grus antigone shsrpii): Implications for reintroduction programs in Thailand. Zool Sci 31 (2): 95-100. DOI: 10.2108/zsj.31.95.

IUCN Red List. 2021. Taxonomy. https://www.iucnredlist.org/. Accessed 13 June 2021

Ivan J, Parikesit AA. 2019. Review article: Computational software for assessing allelic dropout. Indonesian J Life Sci 1 (1): 13-22. DOI: 10.54250/ijls.v1i1.11.

Khaerunnisa I, Sari E, Ulfa M, Jakaria, Sumantri C. 2013. Avian sex determination based on chromo helicase DNA-binding (CHD) genes using polymerase chain reaction (PCR). Media Peternakan 36 (2): 85 90. DOI: 10.5398/medpet.2013.36.2.85.

Kroczak A, Wołoszyńska M, Wierzbicki H, Kurkowski M, Grabowski KA, Piasecki T, Galosi L, Urantówka AD. 2021. New Bird sexing strategy developed in the Order Psittaciformes involves multiple markers to avoid sex misidentification: Debunked myth of the universal DNA Marker. Genes 12 (878): 1-21. DOI: 10.3390/genes12060878.

Lee PLM, Brain PL, Forman DW, Bradbury RB, Griffths R. 2002. Sex and death: CHD1Z associated with high mortality in moorhens. Evolution $56 \quad$ (12): 2548-2553. DOI: $10.1111 / \mathrm{j} .0014-$ 3820.2002.tb00180.x.

Liu H, Li J, Yang F, Cai Y. 2011. Molecular sexing of endangered cranes based on CHD-W Gene. J Appl Anim Res 39 (3): 212-217. DOI: 10.1080/09712119.2011.565225.

Mohanty B, Helder S, Silva APG, Mackay JP, Ryan CP. 2016. The chromatin remodeling protein CHD1 contains a previously unrecognized c-terminal helical domain. J Mol Biol 65 (191): 1-17. DOI: $10.1016 /$ j.jmb.2016.08.028.

Morinha F, Cabral JA, Bastos E. 2012. Molecular sexing of birds : A comparative review of polymerase chain reaction (PCR)-based methods. Theriogenology 78 (4): 703-714. DOI: 10.1016/j.theriogenology.2012.04.015.

Ramos PS, Bastos E, Mannan RW, Guedes-Pinto H. 2009. Polymerase chain reaction-single strand conformation polymorphism applied to sex identification of Accipiter cooperii. Mol Cell Probes 23 (2):115118. DOI: 10.1016/j.mcp.2008.12.002.

Romanov MN, Betuel AM, Chemnick LG, Ryder OA, Kulibaba RO, Tereshchenko OV, Payne WS, Delekta PhC, Dodgson JB, Tuttle EM, Gonser RA. 2019. Widely applicable PCR markers for sex identification in birds. Russ J Genet 55 (2): 220-231. DOI: 10.1134/S1022795419020121.

Simsek M, Adnan H. 2000. Effect of single mismatches at 3'-end of primers on polymerase chain reaction. Med Sci 2 (1): 11-14.

Stevens AJ, Taylor MG, Pearce FG, Kennedy MA. 2017. Allelic drop-out during polymerase chain reaction due to G-quadruplex structures and DNA methylation is widspread at imprinted human loci. Genet Soc Am 7 (3): 1019-1025. DOI: 10.1534/g3.116.038687. 
Sulandari S, Zein MSA. 2012. Application of two molecular sexing methods for Indonesian bird species: Implication for captive breeding programs in Indonesia. HAYATI 19 (4): 183-190. DOI: 10.4308/hjb.19.4.183.

Tezuka A, Matsushima N, Nemoto Y, Akashi HD, Kawata M, Makino T. 2012. Comprehensive primer design for analysis of population genetics in non-sequenced organisms. PLos One 7 (2): e32314. DOI: 10.1371/journal.pone.0032314.
Wang C. 2016. Primer Design. Health Sciences, University of Copenhagen, Denmark.

Yuda P, Saputra. AW. 2020. Eggshell membrane for DNA sexing of the endangered maleo (Macrocephalon maleo). F1000Res 9: 599. DOI: 10.12688/f1000research.23712.4.

Yuni LPEK, Yuda IP. 2019. The Island Biogeography of Wallacea and Krakatoa Island. In: Encyclopedia of the World's Biomes. Elselvier, Netherlands. 